DOI: https://doi.org/10.15276/hait.02.2021.2

UDC 004. $93+681.5 .015$

\title{
HYBRID TEXTURE IDENTIFICATION METHOD
}

\author{
Natalya P. Volkova ${ }^{1)}$ \\ ORCID: https://orcid.org/0000-0003-3175-2179; volkovanp30@gmail.com \\ Viktor N. Krylov ${ }^{1)}$ \\ ORCID: https://orcid.org/0000-0003-1950-4690; viktor.krylov@gmail.com \\ ${ }^{1)}$ Odessa National Polytechnic University, 1, Shevchenko Ave. Odesa, 65044, Ukraine
}

\begin{abstract}
The importance of the modeling mode in systems of computer visual pattern recognition is shown. The purpose of the mode is to determine the types of textures that are present on the images processed in intelligent diagnostic systems. Images processed in technical diagnostic systems contain texture regions, which can be represented by different types of textures - spectral, statistical and spectral-statistical. Texture identification methods, such as, statistical, spectral, expert, multifractal, which are used to identify and analyze texture images, have been analyzed. To determine texture regions on images that are of a combined spectral-statistical nature, a hybrid texture identification method has been developed which makes it possible to take into account the local characteristics of the texture based on multifractal indicators characterizing the non-stationarity and impulsite of the data and the sign of the spectral texture. The stages of the developed hybrid texture identification method are: preprocessing; formation of the primary features vector; formation of the secondary features vector. The formation of the primary features vector is performed for the selected rectangular fragment of the image, in which the multifractal features and the spectral texture feature are calculated. To reduce the feature space at the stage of formation of the secondary identification vector, the principal component method was used. An experimental study of the developed hybrid texture identification method textures on model images of spectral, statistical, spectralstatistical textures has been carried out. The results of the study showed that the developed method made it possible to increase the probability of correct determination of the region of the combined spectral-statistical texture. The developed identification method was tested on images from Brodatz album of textures and images of wear zones of cutting tools, which are processed in intelligent systems of technical diagnostics. The probability of correctly identifying areas of spectral-statistical texture in the images of wear zones of cutting tools averaged 0.9 , which is sufficient for the needs of practice.
\end{abstract}

Keywords: Identification; Texture Model; Multifractal Features; Spectral Texture Feature.

For citation: Volkova N. P., Krylov V. N. Hybrid Texture Identification Method. Herald of Advanced Information Technology. 2021; Vol.4 No.2 : 123-134. DOI: https://doi.org/10.15276/hait.02.2021.2

\section{INTRODUCTION}

Today, systems of computer visual pattern recognition (SCVPR) are widely used in intelligent systems for medical and technical diagnostics, as well as in automated processing of aerospace information.

The basic stages of image processing in SCVPR are: preprocessing, identification, classification, segmentation. Most of the images processed in such systems contain homogeneous regions, which differ in texture and color. At the identification stage, the sample object is built, to which corresponds to a certain area in the feature space. The purpose of identification is to reduce the amount of processed information, sufficient for stable object recognition. Identification of texture type at the identification stage allows improving the quality of automatic image processing in SCVPR of diagnostic systems.

The identification stage allows you to build the sample object in the form of a set of quantitative, qualitative or logical features (primary identification vector) for their further classification.

One of the requirements that are put forward for the primary identification vector is to ensure high reliability

() Volkova N., Krylov V., 2021 of the classification of object images. The most common texture features are: color, geometric, statistical, structural, spectral, and topological. The following methods for identifying homogeneous texture regions in images are known: statistical, spectral, expert evaluation methods, methods based on multifractal indicators. These methods involve the features extraction for the formation of a feature vector depending on the type of texture, which provides high classification reliability in the case when the images contain homogeneous texture regions (spectral or statistical texture). However, images processed in technical diagnostics systems contain, as a rule, regions of combined spectralstatistical texture. In this case, the reliability of object classification based on the hypothesis of homogeneity in the image decreases, which leads to a decrease in the quality of image processing in the SCVPR and affects the result of technical diagnostics.

Thus, the task of developing texture identification method for identifying regions of combined spectral-statistical texture on images that are processed in technical diagnostic systems is relevant.

This is an open access article under the CC BY license (http://creativecommons.org/licenses/by/3.0) 


\section{LITERATURE REVIEW AND PROBLEM STATEMENT}

Analysis of the literature showed that there are a number of methods used to identify homogeneous texture regions on images: statistical, spectral [1, 2], expert estimation [3], multifractal $[4,5]$.

Statistical methods are based on estimating texture measures by analyzing brightness histograms (average brightness; average contrast; relative brightness smoothness of region, using statistical moments [2]. Statistical methods are used to identify statistical, spectral and ordered type of textures.

Let us consider one of the statistical methods the method of moments, which is based on the calculation of moment invariants for estimating texture features [2].

The 2-D moment of order $(p+q)$ of twodimensional continuous function $f(x, y)$, is defined as:

$$
m_{p q}=\iint x^{p} y^{q} f(x, y) d x d y,
$$

where $p, q=0,1,2, \ldots$.

The central moment of order $(p+q)$ is defined as:

$$
\mu_{p q}=\int^{\infty} \int^{\infty}(x-\bar{x})^{p}(y-\bar{y})^{q} f(x, y) d x d y
$$

where $\bar{x}=\frac{m_{10}}{m_{00}}$ and $\bar{y}=\frac{m_{01}}{m_{00}}$.

If $f(x, y)$-digital image, then (1) takes the following form:

$$
\mu_{p q}=\sum_{x} \sum_{y}(x-\bar{x})^{p}(y-\bar{y})^{q} f(x, y) .
$$

The normalized central moment of order $(p+q)$, denoted $\eta_{p q}$, is defined as:

$$
\eta_{p q}=\frac{\mu_{p q}}{\mu_{00}{ }^{y}},
$$

where $\gamma=\frac{p+q}{2}+1$, for $p+q=2,3 \ldots$.

A set of seven moment invariants is derived from the 2nd and 3rd normalized central moments:

$$
\begin{gathered}
\phi_{1}=\eta_{20}+\eta_{02}, \\
\phi_{2}=\left(\eta_{20}-\eta_{02}\right)^{2}+4 \eta_{11}^{2}, \\
\phi_{3}=\left(\eta_{30}-3 \eta_{12}\right)^{2}+\left(3 \eta_{21}-\eta_{03}\right)^{2},
\end{gathered}
$$

$$
\begin{gathered}
\phi_{4}=\left(\eta_{30}+\eta_{12}\right)^{2}+\left(\eta_{21}+\eta_{03}\right)^{2}, \\
\left.\phi_{5}=\left(\eta_{30}-3 \eta_{12}\right)\left(\eta_{30}+\eta_{12}\right) \mid\left(\eta_{30}+\eta_{12}\right)^{2}-3\left(\eta_{21}+\eta_{03}\right)^{2}\right]+ \\
\left(3 \eta_{21}-\eta_{03}\right)\left(\eta_{21}+\eta_{03}\right)\left[3\left(\eta_{30}+\eta_{12}\right)^{2}-\left(\eta_{21}+\eta_{03}\right)^{2}\right] \\
\phi_{6}=\left(\eta_{20}-\eta_{02}\right)\left[\left(\eta_{30}+\eta_{12}\right)^{2}-\left(\eta_{21}+\eta_{03}\right)^{2}\right]+ \\
4 \eta_{11}\left(\eta_{30}+\eta_{12}\right)\left(\eta_{21}+\eta_{03}\right), \\
\left.\phi_{7}=\left(3 \eta_{21}-\eta_{03}\right)\left(\eta_{30}+\eta_{12}\right) \mid\left(\eta_{30}+\eta_{12}\right)^{2}-3\left(\eta_{21}+\eta_{03}\right)^{2}\right]+ \\
\left(3 \eta_{12}-\eta_{03}\right)\left(\eta_{21}+\eta_{03}\right)\left[3\left(\eta_{30}+\eta_{12}\right)^{2}-\left(\eta_{21}+\eta_{03}\right)^{2}\right]
\end{gathered}
$$

The advantage of the method of moments is the high reliability of recognition, and the obtained feature vectors are invariant to rotation, shift and change of scale [2]. The main disadvantage of the method of moments is a low efficiency.

The advantage of the method of moments is the high reliability of recognition, and the obtained feature vector is invariant to rotation, shift and changing scale [2]. The main disadvantage of the method of moments is a low efficiency.

Spectral methods of texture identification use a Fourier spectrum, which takes into account the directionality of texture elements [6-8]. Spectral methods make it possible to move from the analysis of textures in the spatial domain to the analysis of textures in the frequency domain [6]. Spectral methods also include methods based on wavelet transforms, such as Gabor wavelets, which take into account the frequency composition of the texture $[9,10]$. Spectral methods are used to identify ordered and spectral types of textures. The advantage of spectral methods is the high efficiency, but the recognition reliability for very noisy images is not high.

Expert evaluation methods refer to heuristic approach methods, which are expert-based intuition and experience [11, 12]. Experts classify the elements of the image, based on the allocation of the properties of objects that are difficult to formalize. Interviews, dialogs, roundtables, etc. are used to allocate the properties of objects. The advantage of expert evaluation methods is high efficiency and a wide class of problems to be solved, but these methods require the development of separate methods that take into account the specifics of recognition problems, as well as the availability of qualified experts, which make automatic image processing more difficult.

Multifractal methods are used in the nonstationary data, signals and images processing $[13,14]$. Fractal dimension $[15,16]$, due to its spatial invariance, is used to estimate the textural characteristic of images - roughness within the multifractal concept. The use of multifractal features 
of non-stationarity and impulsite, which are invariant to affine transformations of objects on images, in the identification of Gaussian, impulse, multiplicative noise on images [17] allowed to classify these types of noise with high reliability. In [18], multifractal features were used to identify structural, spectral and stochastic models of texture. This method provided a high reliability of texture classification when identifying structural and stochastic models of texture with lower reliability estimation in case spectral model of texture.

The results of identification methods analysis for homogeneous texture regions are summarized in the table (Table 1).

Table 1. Analysis of texture identification methods

\begin{tabular}{|c|c|c|}
\hline $\begin{array}{l}\text { Identification } \\
\text { methods }\end{array}$ & Advantages & Disadvantages \\
\hline Statistical & $\begin{array}{l}\text { High } \\
\text { reliability of } \\
\text { classification } \\
\text { of statistical, } \\
\text { spectral and } \\
\text { ordered type } \\
\text { of texture }\end{array}$ & Low efficiency \\
\hline Spectral & $\begin{array}{l}\text { High } \\
\text { efficiency in } \\
\text { identifying } \\
\text { ordered and } \\
\text { spectral type } \\
\text { of texture }\end{array}$ & $\begin{array}{l}\text { Not high } \\
\text { reliability of } \\
\text { texture } \\
\text { classification } \\
\text { on low quality } \\
\text { images }\end{array}$ \\
\hline Expert & $\begin{array}{l}\text { High } \\
\text { efficiency and } \\
\text { a wide class of } \\
\text { problems that } \\
\text { are difficult to } \\
\text { formalize to be } \\
\text { solved }\end{array}$ & $\begin{array}{l}\text { The need for } \\
\text { qualified } \\
\text { experts }\end{array}$ \\
\hline Multifractal & $\begin{array}{l}\text { High } \\
\text { reliability of } \\
\text { classification } \\
\text { of statistical } \\
\text { and ordered } \\
\text { type of texture }\end{array}$ & $\begin{array}{l}\text { Not high } \\
\text { reliability of } \\
\text { classification } \\
\text { of spectral } \\
\text { type of texture }\end{array}$ \\
\hline
\end{tabular}

Since the technical diagnostics systems analyze images what contain regions of different types of textures (spectral, statistical and combined spectralstatistical) the development an automatic texture identification method for different types of textures is required. It will improve the quality of image processing in SCVPR of these systems and increase the reliability of diagnostic decisions. Taking into account the above advantages and disadvantages of texture identification methods for identifying types of textures, it was proposed to use a multifractal approach. The authors propose to determine combined texture regions on the images considering non-stationarity, impulsite of data and changes in spatial frequency by calculating the features which describing the degree dependence properties of statistic on scale and the spectral texture feature [1].

\section{THE AIM AND OBJECTIVES OF THE RESEARCH}

The aim of this work is to solve the problem of identifying regions of combined spectral-statistical textures to increase the reliability of classification of such textures.

To achieve this, the following tasks have been set:

- developing a hybrid texture identification method for identifying areas;

- conducting an experimental research of the proposed texture identification method during classification for model images;

- conducting an experimental research of the proposed texture identification method during classification of images of wear zones of cutting tools.

\section{HYBRID TEXTURE IDENTIFICATION METHOD}

The conducted analysis of SCVPR of diagnostic systems showed that the image analysis process can be conditionally divided into two modes: modeling and working mode. The quality of automatic processing of texture images depends on the result of the modeling mode stages, in which the type of texture is determined [1].

In [1], the authors carried out a classification of texture regions on images of cutting tool wear zones, which are processed in technical diagnostic systems. It was shown that such images contain texture regions, which are represented by the following models: spectral, statistical, and combined (spectralstatistical). The examples of texture regions on images of cutting tool wear zones are given in Table 2. Appropriate mathematical models (Table 2) have been developed for the analytical description of texture images, where the value of the intensity of the $m$-th row of a texture image of different types of textures is represented as a union of non-intersecting segments.

In formulas (2), (3) and (4) the following designations are taken: $A_{i j}\left(x, y_{m}\right), \omega_{m}^{i j}$ are the amplitude and frequency of the modulated $j$-th oscillation on the $i$-th segment of the $m$-th image raw, respectively, $c_{i}\left(x, y_{m}\right)$ is the notation of the background in the $i$-th segment of the $m$-th image 


\section{Table 2. Description of texture models}

\begin{tabular}{|c|c|c|c|}
\hline Texture model & Spectral & Statistical & Combined \\
\hline $\begin{array}{l}\text { Examples of } \\
\text { cutting tool wear } \\
\text { zone images }\end{array}$ & & & \\
\hline $\begin{array}{l}\text { Analytical } \\
\text { description }\end{array}$ & $\begin{array}{l}I\left(x, y_{m}\right)=\bigcup_{i=1}^{k}\left\{c_{i}\left(x, y_{m}\right)\right. \\
\left.+\sum_{j=1}^{n} A_{i j}\left(x, y_{m}\right) \sin \left(\omega_{m}^{i j} x\right)\right\}\end{array}$ & $\begin{array}{l}I\left(x, y_{m}\right)=\bigcup_{i=1}^{k}\left\{c_{i}\left(x, y_{m}\right)\right. \\
\left.+N_{i}\left(x, y_{m}\right)\right\}\end{array}$ & $\begin{array}{l}I\left(x, y_{m}\right)=\bigcup_{i=1}^{k}\left\{c_{i}\left(x, y_{m}\right)+N_{i}(x, y)\right. \\
\left.+\sum_{j=1}^{n} A_{i j}\left(x, y_{m}\right) \sin \left(\omega_{m}^{i j} x\right)\right\}\end{array}$ \\
\hline
\end{tabular}

Source: compiled by the authors

raw, $q=\left(q_{0}, \ldots, q_{k+1}\right)$ is the vector of boundaries texture regions of the $m$-th image raw, where $q_{0}=1$, $q_{\mathrm{k}+1}=N+1, N$ is the number of pixels in the image raw, $N_{i}(x, y)$ is zero-mean Gaussian noise and variance $\sigma_{i}^{2}$ on the $i$-th image segment, $x \in\left[q_{i-1}, q_{i}\right]$. In this work, the hybrid texture identification method was developed for identification of texture regions, which are described by the combined spectral-statistical model of textures. The schematic diagram of the implementation of the hybrid texture identification method (Fig. 1) is proposed, which contains the following blocks: preprocessing; selecting a rectangular fragment of an image; formation of the primary features vector: evaluation of the multifractal features, evaluation of the spectral texture feature; formation of the secondary features vector.

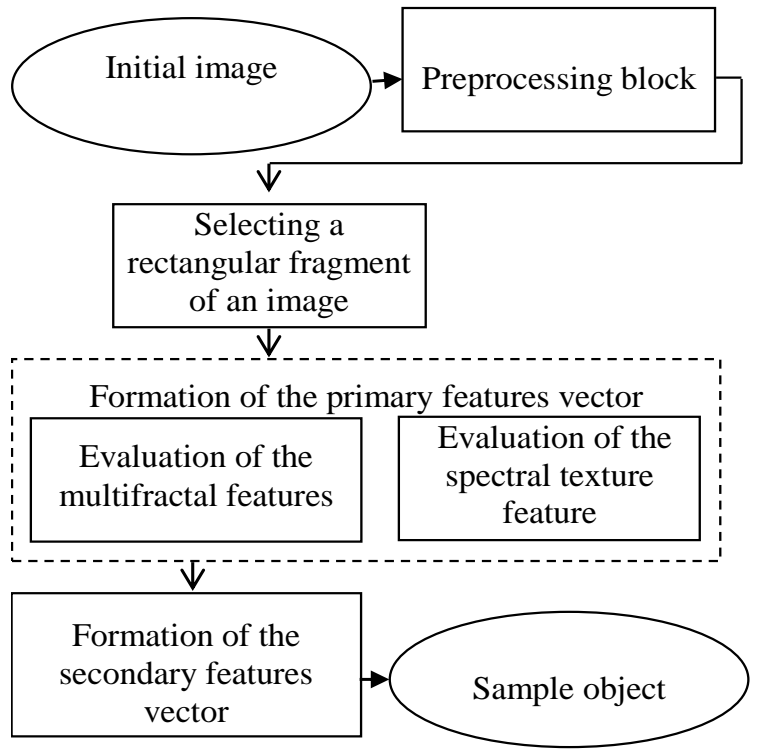

Fig. 1. Schematic diagram of the hybrid texture identification method

Source: compiled by the authors
The noise present on the images which processed in the SCVPR [1], [17] is removed in the preprocessing block. These noises arise in the process of obtaining images for further image processing. The analysis of technical diagnostics systems shown, that the reason of the noises arising is the internal sensors of devices noise and nonuniform illumination of objects of research [18, 19]. In this case there is a multiplicative noise on the images, which is removed by the homomorphic filtering method [2].

Formation of the primary features vector is performed for the selected rectangular fragment of the image of objects of research:

$$
I=\left(H_{x}, H_{y}, H_{x y}, C_{x}, C_{y}, C_{x y}, \sigma\right),
$$

where: $H_{x}, H_{y}, C_{x}, C_{y}, H_{x y}, C_{x y}$ are estimation of multifractal indices $H_{l}, C_{l}$ in $x, y$ and diagonal directions, respectively [18], [21], $\sigma$ is estimation of the spectral texture feature [1].

Multifractal indices $H_{l}, C_{l}$ are used to quantity estimation the non-stationarity and impulsite of the data, respectively. Consider the definition of multifractal indices $H_{l}$ and $C_{l}$ which given in [18].

Let us consider the pixels intensity value of the $i$-th column of the image $I\left(x, y_{i}\right)$, where $x$ is the spatial coordinate of the image pixel, $x=1, \ldots, N, N$ is the number of pixels in the image column. Then multifractal index $H_{l}$ is estimated as the index of degree dependence of the 1st statistical moment for absolute differences values of function $I\left(x, y_{i}\right)$ on the scale.

The difference values of order $r$ of function $I\left(x, y_{i}\right)$ is the value:

$$
\Delta I\left(r, x, y_{i}\right)=I\left(x+r, y_{i}\right)-I\left(x, y_{i}\right),
$$

where $x=1, \ldots, N-r, y$ is the spatial coordinate. 
The absolute differences values of function $I\left(x, y_{i}\right)$ is $\left|\Delta I\left(r, x, y_{i}\right)\right|$.

The multifractal index $H_{l}$ is a special case of the function $\varsigma(\tau)$, which is the estimate of degree dependence of the $\tau$ order statistical moment for absolute differences values of function $I\left(x, y_{i}\right)$ on the scale $r$, when $\tau=1$.

To determine the value of the function $\varsigma(\tau)$ the expression is used:

$$
\ln \left(\frac{1}{N} \sum_{x=1}^{N}\left|\Delta I\left(1, x, y_{i}\right)\right|^{\tau}\right)=\varsigma(\tau) \ln \left(\frac{r}{N}\right)+\ln c(r),(6)
$$

where $c(r)$ is the approximation error.

Then multifractal indices $H_{1}=\varsigma(1)(7)$ is found by determining parameters of linear regression dependences $\ln \left(\frac{1}{N} \sum_{x=1}^{N}\left|\Delta I\left(1, x, y_{i}\right)\right|\right)$ from $\ln \left(\frac{r}{N}\right)$.

The image pixel intensity value in terms of value of singular measures is characterized by multifractal index $C_{l}$, which is defined as the derivative the degree dependence of the singular measure on the scale $K(\tau)$ and is calculated as:

$$
\ln \left(\frac{1}{N} \sum_{x=1}^{N} \varepsilon\left(r, x, y_{i}\right)^{\tau}\right)=-K(\tau) \ln \left(\frac{r}{N}\right)+\ln c^{\prime}(r) .
$$

The concept of the normalized difference values of 1 st order is the basis of the definition of a singular measure. The value of the normalized difference of 1 st order is calculated as:

$$
\begin{gathered}
\varepsilon\left(1, x, y_{i}\right)=\frac{\left|\Delta I\left(1, x, y_{i}\right)\right|}{\left\langle\left|\Delta I\left(1, x, y_{i}\right)\right|\right\rangle}, x=1, \ldots, N-1, \\
\left\langle\left|\Delta I\left(1, x, y_{i}\right)\right|\right\rangle=\frac{1}{N} \sum_{x=1}^{N}\left|\Delta I\left(1, x, y_{i}\right)\right| .
\end{gathered}
$$

To determine the singular measure at different scale values $r=1,2,4, \ldots, N$ the value is entered:

$$
\varepsilon\left(r, x, y_{i}\right)=\frac{1}{r} \sum_{x^{\prime}=x}^{x+r-1} \varepsilon\left(1, x^{\prime}, y_{i}\right), x=1, \ldots, N-r .
$$

Then, the multifractal measure $C_{l}$, is defined as an approximation of the derivative $K(\tau)$ at point $\tau=1: \quad C_{1}=K^{\prime}(1) \geq 0$ (7) with a linear regression dependence $\ln \left(\frac{1}{N} \sum_{x=1}^{N} \varepsilon\left(r, x, y_{i}\right)\right)$ from $\ln \left(\frac{r}{N}\right)$.

Evaluation of a spectral texture feature is performed for each of the image pixel line by line in the sliding window, the size of which is selected depending on the purpose of processing [1]:

1) the direct Fourier transform is performed:

$$
\begin{gathered}
\hat{I}(\omega)=\frac{1}{M} \sum_{x_{i}=1}^{M-1} I\left(x_{i}, y_{m}\right) e^{-j 2 \pi \omega x_{i} / M}, \\
\omega=\overline{0, M-1} .
\end{gathered}
$$

2) the transformation the spectral composition of the texture into spread is performed by the linear transformation of frequency: $z(\omega)=k \cdot \hat{I}(\omega)$.

$3)$ the inverse Fourier transform is performed $I\left(x_{i}, y_{m}\right)=\sum_{\omega=1}^{M-1} z(\omega) e^{j 2 \pi \omega x_{i} / M}, x_{i}=\overline{0, M-1}$;

4) the statistical evaluation of the numerical variance characteristics is calculated by the squareamplitude transformation:

$$
\bar{\sigma}=\frac{\sum_{i=1}^{M}\left(I_{i}-\bar{I}\right)^{2}}{M},
$$

where $I_{i}>\bar{I}, i=\overline{1, M}$.

The principal components method is usually used for the selection of the most informative features at the stage formation of the secondary features vector (Fig. 1). According to this method, the dimensional reduction of the features vector is performed by calculating the eigenvectors and eigenvalues of covariance matrix of source data [2].

\section{EXPERIMENTAL RESEARCH OF THE HYBRID TEXTURE IDENTIFICATION METHOD ON MODEL IMAGES}

An experimental research of the developed hybrid texture identification method was conducted out for model texture images (Table 3), as a result of which, for each type of textures, primary identification vectors of features were obtained (Table 3).

To construct dividing surfaces in the modeling mode, preliminary training was carried out by the discriminant analysis method [2]. For this, a training set containing 35 image fragments of each texture type was used, a hybrid identification method was used, dividing surfaces were built, and the corresponding decision rules for the texture type classification were formed.

At the working stage, the developed hybrid texture identification method was applied to the images from the test sample, and then, according to the obtained decision classification rules, it was determined to which class the texture image from the test sample belongs.

Figure 3 shows the result of classification of model texture images in the feature space of two main components $a_{1}$ and $a_{2}$ for spectral-statistical (Fig. 3a), statistical (Fig. 3b) and spectral (Fig. 3c) texture. 
Table 3. Primary identification vector for different types of textures

\begin{tabular}{|c|c|c|c|}
\hline \multirow[b]{3}{*}{$I$} & \multicolumn{3}{|c|}{ Model texture image } \\
\hline & Spectral & Statistical & $\begin{array}{l}\text { Spectral - } \\
\text { statistical }\end{array}$ \\
\hline & & & \\
\hline$H_{x}$ & 0,191 & 0,115 & 0,486 \\
\hline$H_{y}$ & 0,139 & 0,145 & 0,154 \\
\hline$H_{x v}$ & 0,186 & 0,238 & 0,398 \\
\hline$C_{x}$ & 0,455 & 0,838 & 0,737 \\
\hline$C_{y}$ & 0,016 & 0,017 & 0,141 \\
\hline$C_{x y}$ & $-0,014$ & 0,058 & 0,162 \\
\hline$\sigma$ & 0,108 & 0,008 & 0,256 \\
\hline
\end{tabular}

The dividing properties of the obtained identification vector were explored (Fig. 2).
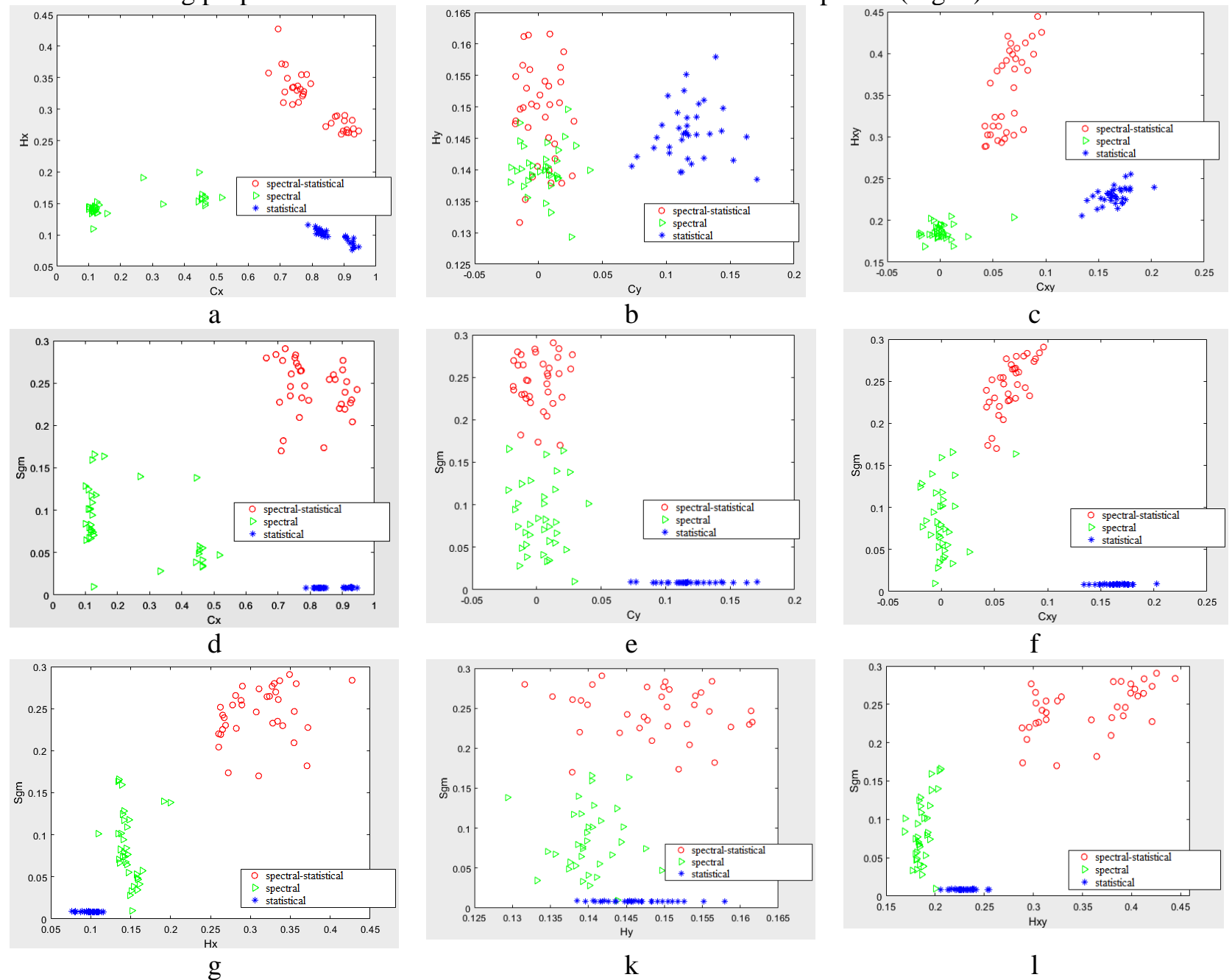

Fig. 2. Image of classes of $\mathbf{3}$ types of textures in a two-dimensional feature space:

$$
\begin{aligned}
& \mathrm{a}-\{\boldsymbol{H} \boldsymbol{x}, \boldsymbol{C x}\} ; \mathrm{b}-\{\boldsymbol{H y}, \boldsymbol{C y}\} ; \mathrm{c}-\{\boldsymbol{H} x \boldsymbol{C}, \boldsymbol{C x y}\} ; \mathrm{d}-\{\sigma, \boldsymbol{C x}\} ; \mathrm{e}-\{\sigma, C y\} ; \\
& \mathbf{f}-\{\sigma, \boldsymbol{C x y}\} ; \mathbf{g}-\{\sigma, \boldsymbol{H x}\} ; \mathbf{k}-\{\sigma, \boldsymbol{H y}\} ; \mathbf{l}-\{\sigma, \boldsymbol{H} \boldsymbol{x y}\}
\end{aligned}
$$

Source: compiled by the authors 


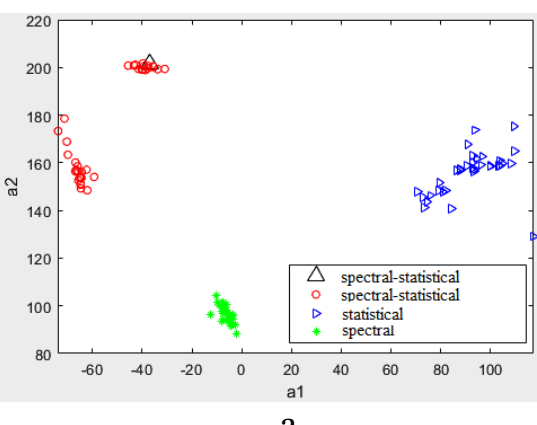

a

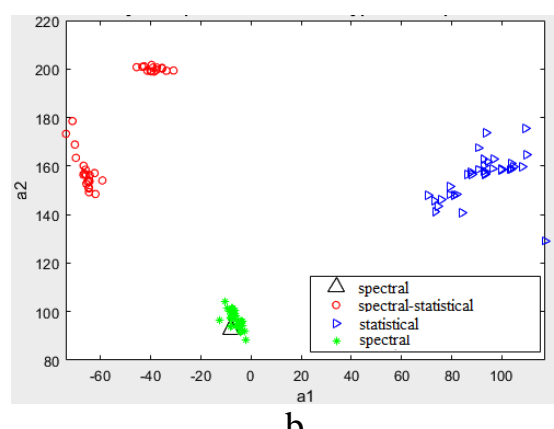

b

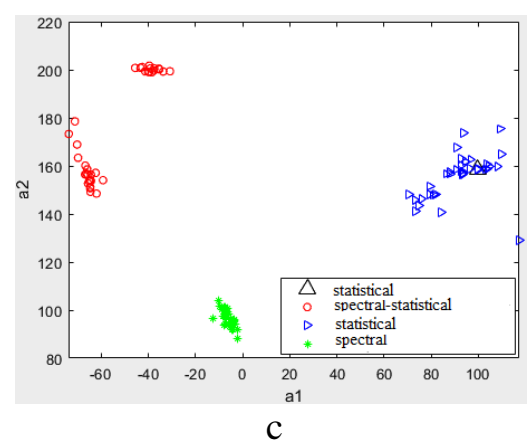

c

Fig. 3. Graphical representation of the classification result in the feature space $a_{1}$ и $a_{2}$ for texture: a - spectral-statistical; b - statistical; c - spectral Source: compiled by the authors

For a quantitative assessment of the reliability of the classification, the probabilities of false positive and false negative errors were determined, based on the confusion matrix [22]. Let the background hypothesis $\mathrm{H}_{0}$ - the pixels belong to the region of interest, the alternative (competing) hypothesis $\mathrm{H}_{1}$, which rejects the background hypothesis - the pixels do not belong to the region of interest, then if the background hypothesis $\mathrm{H}_{0}$ is correct, but it is rejected, we have an error of the 1st kind (the probability of rejecting background hypothesis). If the background hypothesis $\mathrm{H}_{0}$ is incorrect (the competing hypothesis $\mathrm{H}_{1}$ is correct), but it is accepted, we have an error of the 2 nd kind (the probability of rejecting the competing hypothesis). The results are shown in Table 4.

Table 4. Results of classification of different types of textures

\begin{tabular}{|c|c|c|c|}
\hline $\begin{array}{c}\text { Type of } \\
\text { texture }\end{array}$ & Spectral & Statistical & $\begin{array}{c}\text { Spectral - } \\
\text { statistical }\end{array}$ \\
\hline Spectral & 0,98 & 0 & 0,05 \\
\hline Statistical & 0 & 0,96 & 0,01 \\
\hline $\begin{array}{c}\text { Spectral - } \\
\text { statistical }\end{array}$ & 0,02 & 0,04 & 0,94 \\
\hline \multicolumn{3}{|c|}{ Source: compiled by the authors } \\
\hline
\end{tabular}

Thus, the analysis of the obtained results showed that the developed hybrid identification method allows one to correctly identify three types of textures in images. Thus, the spectral texture was correctly determined with a probability of 0.98 with a false alarm probability of 0.02 ; the probability of correct determining the statistical texture was 0.96 , while the probability of a false alarm was 0.04 ; the probability of correct determination of the spectralstatistical texture was 0.94 with a false alarm probability of 0.06 .

\section{APPROBATION OF THE HYBRID TEXTURE IDENTIFICATION METHOD ON TEXTURE IMAGES}

The testing of the hybrid texture identification method operation was carried out on the marked images from Brodatz album and images of cutting tool wear zones using technique which was described above.

Fifty $512 \times 512$ images were selected from the Brodatz album to identify the type of textures in the modeling mode [23]. To formation a sampling for each texture images a sample texture was constructing by the developed hybrid texture identification method (Fig. 1). Size of the test sampling was 105 image fragments.

To check the work of the classifier at the working stage, a texture fragment was cut from the texture images from Brodatz album, for which a sample texture was constructed using the hybrid identification method, and on the basis of the decision classification rules, the class to which the constructed texture image belonged was determined.

Figure 4 shows the result of classification of texture images in the feature space of two main components $a_{1}$ and $a_{2}$ for spectral-statistical (Fig. 4a), statistical (Fig. 4b) and spectral (Fig. 4c) textures.

To assess the quality of the developed hybrid identification method for texture images from Brodatz album, the reliability of the classification the types of texture was determined (Table 5).

\section{Table 5. Results of classification of different types of textures}

\begin{tabular}{|c|c|c|c|}
\hline $\begin{array}{c}\text { Type of } \\
\text { texture }\end{array}$ & Spectral & Statistical & $\begin{array}{c}\text { Spectral - } \\
\text { statistical }\end{array}$ \\
\hline Spectral & 0,96 & 0,01 & 0,05 \\
\hline Statistical & 0,01 & 0,98 & 0,02 \\
\hline $\begin{array}{c}\text { Spectral - } \\
\text { statistical }\end{array}$ & 0,03 & 0,01 & 0,93 \\
\hline
\end{tabular}

Source: compiled by the authors 


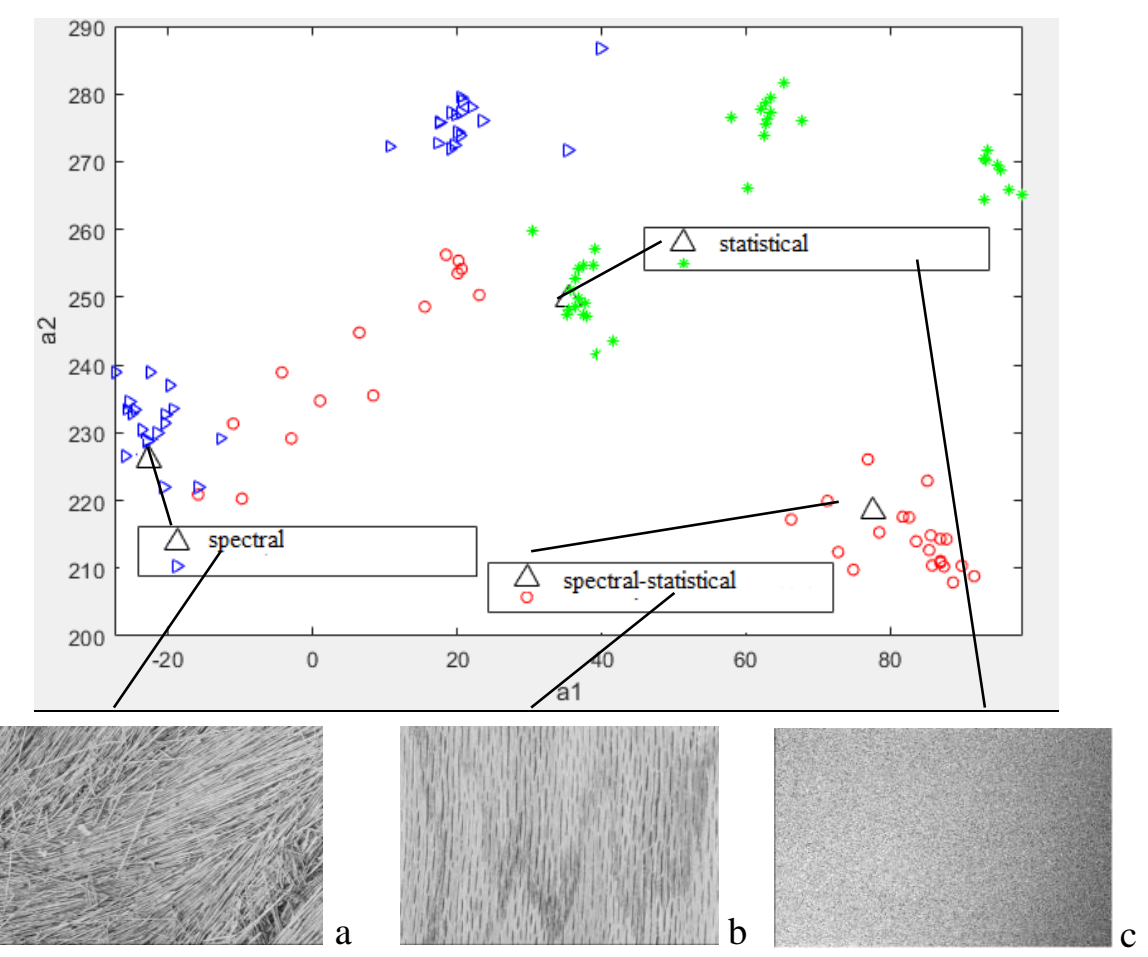

Fig. 4. The results of classification in the space of attributes $a_{1}$ and $a_{2}$ of texture models:

a - spectral-statistical; b - statistical; c - spectral

Source: compiled by the authors

Analysis of the classification results showed that the probability of correct determination of homogeneous texture regions of the spectral texture was 0.96 with a false alarm probability of 0.04 ; the probability of correct determination homogeneous texture regions of the statistical texture is 0.98 with the probability of a false alarm - 0.02; the probability of correct determination of homogeneous texture regions of the spectral-statistical texture was 0.93 with a false alarm probability of 0.07 .

In the technical diagnostics systems of the wear zones of cutting tools, the wear zones of cutting tools are monitored to detect at an early stage tool defects that have a different type of texture. Timely detection of wear zones of cutting tools prevents wear of equipment, a decrease in the quality of processing of parts and the number of defective products.

As mentioned above, one of the stages in image processing in diagnostic systems is the preprocessing stage, at which the quality of the images of the object under study is improved by eliminating noise in the images. So, for example, the analysis of images of wear zones of cutting tools, which are processed in SCVPR systems of technical diagnostics [16, 17], showed that they contain noises of different types. The source of additive Gaussian interference is the intrinsic noises of the sensors of the system and the camera; due to uneven illumination of the wear zones of cutting tools, a multiplicative interference occurs. There may also be impulse noise that occurs during quantization in the digital image acquisition process. The signal-tonoise ratio for images of CM wear zones is 17-30 in terms of power. Examples of images and the results of preprocessing of images of the wear zones of cutting tools are presented in Table 6.

Table 6. Results of homomorphic filtering of images of wear zones of cutting tools

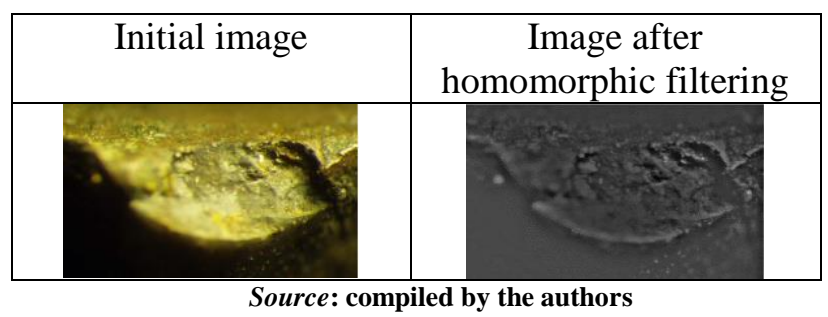

To establish the type of textures of the wear zones of cutting tools, a sampling was considered, consisting of 50 images of wear zones of cutting tools, which were obtained in the course of experiments under the guidance of DSc. A. Derevianchenko.

To identify the type of textures on the images of the wear zones of cutting tools, the images were filtered with a homomorphic filter at the stage of preprocessing (Fig. 1). Next, a hybrid texture identification method was applied to the obtained images (Fig. 1). During the experiment, it was found that the images of the wear zones of cutting tools contain fragments of textures of different types spectral, spectral-statistical, statistical (Table 7, column 3). 
Table 7. Results of the classification of the texture type for the images of the wear zones of cutting tools

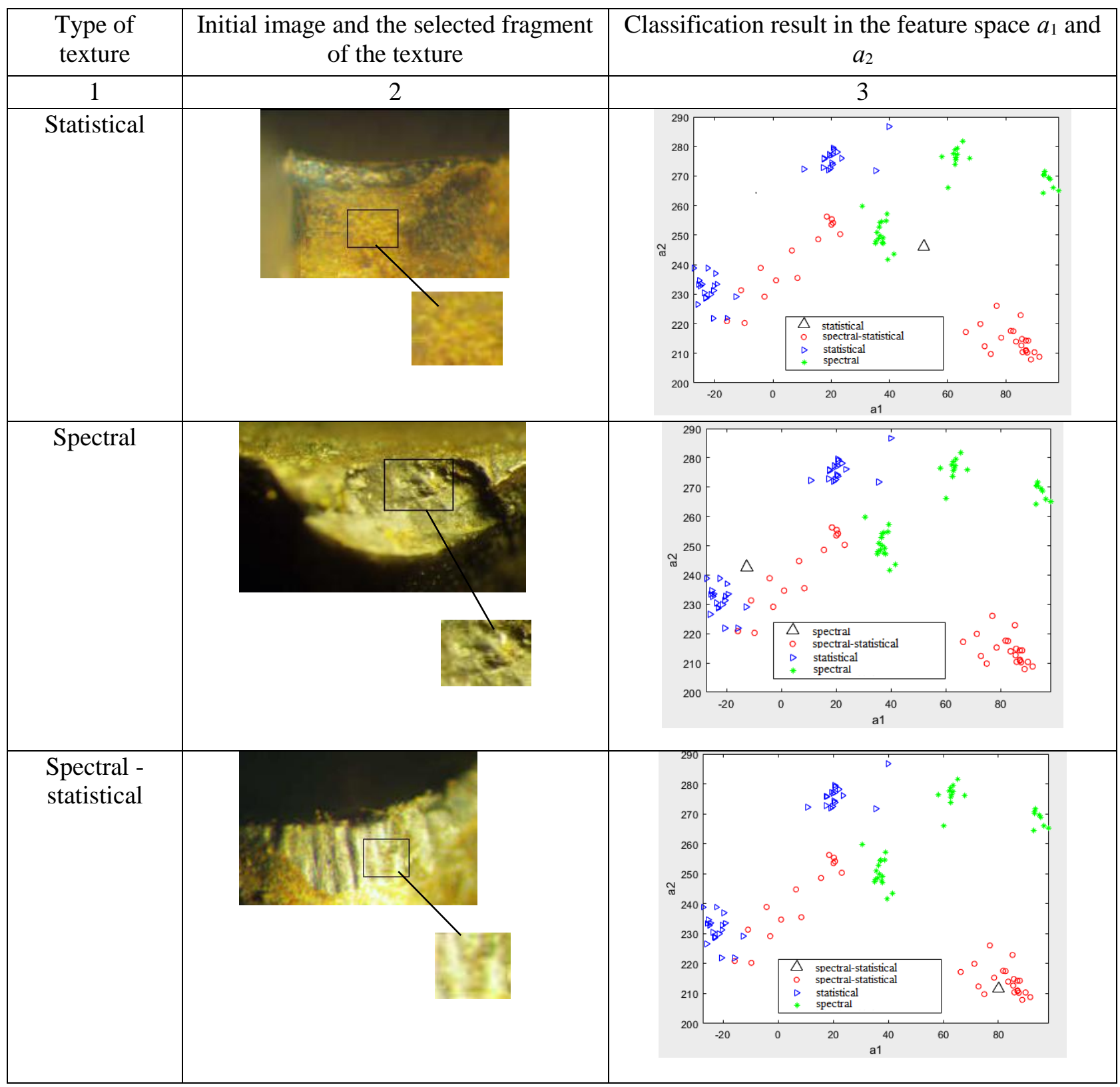

Source: compiled by the authors

Table 7 shows examples of images of the wear zones of cutting tools that can be described by different texture models: a statistical model (roughness and small chipping as a result of random disturbances during cutting) (Table 7 , row 1 ), a spectral texture model (roughness and brittle fracture, as a consequence of slow disturbances of the cutting system) (Table 7, row 2), as well as the combined spectral-statistical model of the texture, when images of the wear zones of cutting tools contains texture features that are inherent in both spectral and statistical texture models (Table 7, row 3).

As a result of the experiment research, the reliability of the classification of homogeneous textured regions on the images of the wear zones of cutting tools was assessed (Table 8).
Table 8. Results of classification of different types of textures on the images of the wear zones of cutting tools

\begin{tabular}{|c|c|c|c|}
\hline $\begin{array}{c}\text { Type of } \\
\text { texture }\end{array}$ & Spectral & Statistical & $\begin{array}{c}\text { Spectral - } \\
\text { statistical }\end{array}$ \\
\hline Spectral & 0,93 & 0,01 & 0,07 \\
\hline Statistical & 0,02 & 0,95 & 0,03 \\
\hline $\begin{array}{c}\text { Spectral - } \\
\text { statistical }\end{array}$ & 0,05 & 0,04 & 0,9 \\
\hline \multicolumn{3}{|c|}{ Source: compiled by the authors } \\
\hline
\end{tabular}

The analysis of the obtained results showed that the probability of correct determination of homogeneous textural regions of the spectral texture on the images of the wear zones of cutting tools was 0.93 with a false alarm probability of 0.07 ; the 
probability of correctly detecting homogeneous texture regions of the statistical texture is 0.95 with the probability of a false alarm - 0.05; the probability of correctly determining the regions of the spectral-statistical texture was 0.9 with a false alarm probability of 0.1 , which is sufficient for the needs of practice.

\section{CONCLUSIONS}

In this work, the problem of identifying texture regions, which are described by a combined spectral-statistical texture model, has been solved.

A hybrid texture identification method has been developed, which made it possible to classify texture regions of a combined spectral-statistical texture with high reliability.

An experimental research of the developed hybrid identification method on model images of spectral, statistical and combined spectral-statistical texture has been carried out. The probability of correct detection of the spectral-statistical texture was 0.94 , the statistical one -0.96 , and the spectral one -0.98 .

The developed hybrid identification method was tested on texture images from Brodatz album and on images of the wear zones of cutting tools. For images from Brodatz album, it was found that the probability of correct determination of homogeneous texture regions of the spectral texture was 0.96 , the statistical one -0.98 , and the spectral-statistical 0.93. For images of the wear zones of cutting tools, the probability of correct determination of homogeneous texture regions of the spectral texture was 0.93 , the statistical texture -0.95 ; spectralstatistical texture -0.9 .

Thus, the developed hybrid texture identification method can be recommended for use at the stage of modeling in SCVPR for technical diagnostic systems of the wear zones of cutting tools, to increase the reliability of classification of texture regions of the wear zones of cutting tools, which can be represented by a combined spectralstatistical texture model.

\section{REFERENCES}

1. Krylov, V. N. \& Volkova, N. P. "Vector-Difference Texture Segmentation Method in Technical and Medical Express Diagnostic Systems". Herald of Advanced Information Technology. Publ. Nauka $i$ Tekhnika. Odessa: Ukraine. 2020; Vol.3 No.4: 174 - 186. DOI: https://doi.org/10.15276/hait.04.2020.2.

2. Gonzalez, R. \& Woods, R. "Digital Image Processing (4th edition)". New York: USA. Publ. Pearson, 2018.1020 p. ISBN 978-0-13-335672-4.

3. Boltenkov, V., Kuvaieva, V., Galchonkov, O. \& Ishchenko, A. "The Research of Possibilities for Fast Calculation of Median Consensus Rankings". Eastern European Journal of Enterprise Technology. Ukraine. 2018; Vol. 4 No. 4: 27-35. DOI: https://doi.org/10.15587/1729-4061.2018.140686.

4. Reljin, I., Reljin, B., Pavlovic, I. \& Rakocevic, I. "Multifractal Analysis of Gray-Scale Images". 2000 10th Mediterranean Electrotechnical Conference. Information Technology and Electrotechnology for the Mediterranean Countries. Proceedings of the MeleCon. Lemesos: Cyprus. 2000; Vol.2: 490-493. DOI: https://doi.org/10.1109/MELCON.2000.879977.

5. Sun, W., Xu, G., Gong, P. \& Liang, S. "Fractal Analysis of Remotely Sensed Images: A Review of Methods and Applications". International Journal of Remote Sensing. Publ. Taylor \& Francis. 2006; Vol. 27 No. 22: 4963-4990. DOI: https://doi.org/ 10.1080/01431160600676695.

6. Fralenko, V. P. "Methods for texture analysis of images, processing of Earth remote sensing data" (in Russian). Software Systems, theory tnd Applications. 2014; No.4(22): 10-29.

7. Hu, X. \& Ensor, A. "Fourier Spectrum Image Texture Analysis". Image and Vision Computing New Zealand (IVCNZ): Proceedings of the 2018 International Conference. Auckland: New Zealand. 2018. p. 19-21. DOI: https://doi.org/ 10.1109/IVCNZ.2018.8634740.

8. Derevyanchenko, A. G., Babilunha, O. Yu., Socenko, A. O. \& Dolishchinskij, R. G. "Recognition of the Textures of the Wear Zones of Cutting Tools Based on the Analysis of the Fourier Energy Spectra of Their Images" (in Russian). Modern Technology in Mechanical. NTU "KhPI". Kharkiv: Ukraine. 2010; Vol. 5: 250-257.

9. Gang Zhang, G. \& Ma, Zong-Min. "Texture Feature Extraction and Description Using Gabor Wavelet in Content-Based Medical Image Retrieval". 2007 International Conference on Wavelet Analysis and Pattern Recognition: Proceedings of the 2007 International Conference on Wavelet Analysis and Pattern Recognition. Beijing: China. 2007. p. 169-173. DOI: https://doi.org/10.1109/ ICWAPR.2007.4420657. 
10. Volkova, N. P. "Detector Quasi-Periodic Texture Segmentation Method for Dermatological Images Processing”. Herald of Advanced Information Technology. Publ. Nauka i Tekhnika. Odessa: Ukraine. 2019; Vol. 2, No. 4: 259-267. DOI: https://doi.org/10.15276/hait.04.2019.2.

11. Carine Lallemand, Vincent Koenig \& Guillaume Gronier. "How Relevant Is an Expert Evaluation of User Experience Based on a Psychological Needs-Driven Approach?". 8th Nordic Conference on HumanComputer Interaction: Fun, Fast, Foundational (NordiCHI '14). Proceedings of the NordiCHI '14. New York: NY. USA. 2014. p.11-20. DOI: https://doi.org/10.1145/2639189.2639214.

12. Van Landeghem, Sofie et al. "Discriminative and Informative Features for Biomolecular Text Mining with Ensemble Feature Selection”. Bioinformatics (Oxford, England). 2010; Vol. 26(18): i554-i560. DOI: https://doi.org/10.1093/bioinformatics/btq381.

13. Calif, R. \& Schmitt, F. G. "Multiscaling and Joint Multiscaling Description of the Atmospheric Wind Speed and the Aggregate Power Output from a Wind Farm". Nonlin. Processes Geophys. 2014: Vol. 21: 379-392. DOI: https://doi.org/10.5194/npg-21-379-2014.

14. Calif, R., Schmitt, F. G., Huang, Y. "Multifractal Description of Wind Power Fluctuations Using Arbitrary Order Hilbert Spectral Analysis". Physica A: Statistical Mechanics and its Applications. 2013; Vol. 392 (18): 4106-4120. DOI: https://doi.org/10.1016/j.physa.2013.04.038.

15. Murugeswari, G., Suruliandi, A. "Fuzzy Based Visual Texture Feature for Psoriasis Image Analysis". World Academy of Science, Engineering and Technology International Journal of Computer and Information Engineering . 2015; Vol. 8 No.10: 1931-1938. DOI: https://doi.org/10.5281/zenodo.1099882.

16. Abiyev, R. \& Kilic, K. I. "An Efficient Fractal Measure for Image Texture Recognition". Fifth International Conference on Soft Computing, Computing with Words and Perceptions in System Analysis, Decision and Control: Proceedings of the Fifth International Conference on Soft Computing, Computing with Words and Perceptions in System Analysis, Decision and Control. Famagusta: North Cyprus. 2009. p. 1-4. DOI: https://doi.org/10.1109/ICSCCW.2009.5379454.

17. Emec, Yu. V. "Estimation of the Parameter of Multiplicative Noise in the Image Using Multifractal Indicators" (in Russian). Artificial Intelligence. Donetsk: Ukraine. 2010; No.4: 212-220.

18. Krylov, V. N., Polyakova, M. V. \& Emec, YU. V. " Recognition of Classes of Texture Images Using Multifractal Indicators" (in Russian). Modern Information and Electronic Technologies: Proceedings of the 12th International Scientific and Practical Conference. ONPU. Odesa: Ukraine. May 23-27, 2011. 74 p.

19. Mehta, S., Singh, R. A., Mohata, Y. \& Kiran, M. B. "Measurement and Analysis of Tool Wear Using Vision System". Industrial Engineering and Applications (ICIEA-2019): Proceedings of the 2019 IEEE 6th International Conference. Tokyo: Japan. 2019. p. 45-49. DOI: https://doi.org/10.1109/ IEA.2019.8715209.

20. Peng, R., Pang, H., Jiang, H. \& Hu, Y. "Study of Tool Wear Monitoring Using Machine Vision". Automatic Control and Computer Sciences. 2020; Vol.54 No.3: 259-270. DOI: https://doi.org/10.3103/ s0146411620030062.

21. Volkova, N. P. "Method for Identifying Textured Regions of Images" (in Ukrainian). Project, Program, Portfolio Management (P3M-2020): Proceedings of the 3th International Research Conference. Odesa: Ukraine. December 04-05, 2020. p. 187-191.

22. Arsirii, O., Manikaeva, O., Nikolenko, A. \& Babilunha,O. "Heuristic Models and Methods for Application of the Kohonen Neural Network in the Intellectual System of Medical-Sociological Monitoring". Herald of Advanced Information Technology. Publ. Nauka i Tekhnika. Odesa: Ukraine. 2020; Vol.3 No.1: 395-405. DOI: https://doi.org/10.15276/hait 01.2020.6.

23. Brodatz, P. "Textures: A Photographic Album for Artists and Designers". Dover Publications. New York: NY. USA. 1966.

Conflicts of Interest: the authors declare no conflict of interest

Received. $\quad 12.11 .2020$

Received after revision 26.02.2021

Accepted 16.03.2021 


\title{
DOI: https://doi.org/10.15276/hait.02.2021.2 \\ УДК 004. 93 + 681.5.015
}

\section{ГІБРИДНИЙ МЕТОД ІДЕНТИФІКАЦІЇ ТЕКСТУРНИХ ОБЛАСТЕЙ}

\author{
Наталія Павлівна Волкова ${ }^{1)}$ \\ ORCID: https://orcid.org/0000-0003-3175-2179; volkovanp30@gmail.com \\ Віктор Миколайович Крилов ${ }^{1)}$ \\ ORCID: https://orcid.org/0000-0003-1950-4690; viktor.krylov@gmail.com \\ 1) Одеський національний політехнічний університет, пр. Шевченка, 1. Одеса, 65044, Україна
}

\begin{abstract}
АНОТАЦІ
Показана важливість режиму моделювання в системах комп'ютерного розпізнавання зорових образів, метою якого $є$ визначення типів текстур, які присутні на зображеннях, що обробляються в інтелектуальних діагностичних системах. Зображення, оброблювані в системах технічної діагностики, містять текстурні області, які можуть бути представлені різними типами текстур - спектральної, статистичної, спектрально-статистичної. Проаналізовано методи ідентифікації типів текстур, такі як, статистичні, спектральні, експертні, мультифрактальні, які застосовуються для ідентифікації та аналізу текстурних зображень. Для визначення на зображеннях текстурних областей, які носять комбінований спектральностатистичний характер, розроблено гібридний метод ідентифікації текстурних областей, який дозволяє враховувати локальні характеристики текстури на основі мультифрактального показників, що характеризують нестаціонарність i імпульсність даних і ознаку спектральної текстури. Етапами розробленого гібридного методу ідентифікації текстур є: попередня обробка; формування первинного ідентифікаційного вектора; формування вторинного ідентифікаційного вектора. Формування первинного ідентифікаційного вектора проводиться для виділеного прямокутного фрагмента зображення, в якому розраховуються мультифрактальні показники і ознака спектральної текстури. Для зменшення простору ознак на етапі формування вторинного ідентифікаційного вектора застосовувався метод головних компонент. Проведено експериментальне дослідження розробленого гібридного методу ідентифікації текстур на модельних зображеннях спектральної, статистичної, спектрально-статистичної текстур. Результати дослідження показали, що розроблений метод дозволив підвищити ймовірність правильного визначення області комбінованої спектрально-статистичної текстури. Апробація розробленого методу ідентифікації проводилася на зображеннях з альбому текстур Бродаца і зображеннях зон зносу ріжучих інструментів, які обробляються в інтелектуальних системах технічної діагностики. Імовірність правильного визначення областей спектрально-статистичної текстури на зображеннях зон зносу ріжучих інструментів склала в середньому 0,9, що є достатнім для потреб практики.
\end{abstract}

Ключові слова: Ідентифікація; модель текстури; мультифрактальні показники; ознака спектральної текстури

\section{ABOUT THE AUTHORS}

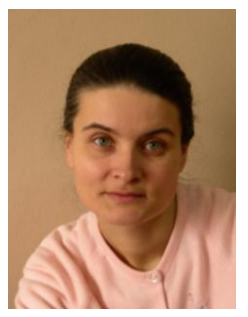

Natalya P. Volkova - Senior Lecturer of Department of Applied Mathematics and Information Technology. Odessa National Polytechnic University, 1, Shevchenko Ave. Odesa, 65044, Ukraine ORCID: https://orcid.org/0000-0003-3175-2179; volkovanp30@ gmail.com Research field: Digital Image Processing; Pattern Recognition

Наталія Павлівна Волкова -старший викладач кафедри Прикладної математики та інформаційних технологій, Одеського національного політехнічного університету, пр. Шевченка, 1. Одеса, 65044, Україна

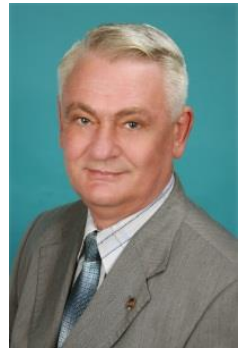

Viktor N. Krylov - Dr. Sci. (Eng), Professor Department of Applied Mathematics and Information Technology. Odessa National Polytechnic University.1, Shevchenko Ave. Odesa, 65044, Ukraine ORCID: https://orcid.org/0000-0003-1950-4690; viktor.krylov@gmail.com Research field: Digital Image Processing; Pattern Recognition

Віктор Миколайович Крилов - професор, доктор технічних науккафедра Прикладної математики і інформаційних технологій Одеського національного політехнічного університету, пр. Шевченка, 1. Одеса, 65044, Україна 